\title{
CONTENT ANALYSIS OF BANK DISCLOSURES RELATED TO ESG RISKS ${ }^{1}$
}

\author{
A snapshot of the disclosure practices of large domestic banks \\ Zsuzsanna Tamásné Vöneki - Gabriella Lamanda
}

\begin{abstract}
The current article focuses on ESG risks. Taking into account ESG aspects, and the expectations and guidelines related to public reports on ESG risks, we created a list of questions, based on which we evaluated the reports of nine large domestic banks published in 2019. Based on a content analysis of the reports, we can confirm the hypothesis that ESG risks are not built into the risk management process and are not defined as independent risks, and that the ESG framework does not have a dedicated organization. The management of ESG risks is unstructured and only partially reflected in domestic practice, and since there is no uniform requirement for disclosure, heterogeneous reports and information content are typical. The main problem can be seen in the absence of a definition of the ESG framework. Related to the three issues (the environment, social responsibility, and corporate governance), banks lag far behind in integrating environmental considerations into lending policy.
\end{abstract}

JEL codes: $\mathrm{G}_{21}, \mathrm{G}_{32}, \mathrm{G}_{3} 8$

Keywords: ESG, risk management, disclosure, banking

1 This research in case of Zsuzsanna Tamásné Vöneki was supported by the Higher Education Institutional Excellence Program 2020 of the Ministry of Innovation and Technology in the framework of the, Financial and Public Services' research project at Corvinus University of Budapest.

2 Zsuzsanna Tamásné Vöneki OTP Bank Nyrt., Operational Risk Management Department; Department of Finance, Corvinus University of Budapest, e-mail: zsuzsanna.voneki@uni-corvinus.hu Gabriella Lamanda OTP Bank Nyrt., Operational Risk Management Department; Eötvös Loránd University, Institute of Business Economics, e-mail: lamanda.gabriella@gti.elte.hu 


\section{INTRODUCTION}

In recent years ESG aspects have come to the fore, and it is expedient and sometimes obligatory for companies - regardless of the sector - to take such aspects into account in their operations. ESG (Environmental, Social and Governance) covers the environmental, social and corporate governance aspects that play a key role in corporate value creation and long-term profitable operations. The table below summarizes the main elements of the three pillars of the ESG framework.

Table 1

Elements of the ESG framework

\begin{tabular}{lll}
\hline Environmental & Social & Governance \\
\hline $\begin{array}{l}\text { Climate change } \\
\text { (CO2 emissions) }\end{array}$ & $\begin{array}{l}\text { Human resources } \\
\text { (workplace safety, } \\
\text { Natural resources } \\
\text { (water, raw materials, biodiversity) }\end{array}$ & $\begin{array}{l}\text { Product safety } \\
\text { (data security, responsible }\end{array}$ \\
$\begin{array}{l}\text { Environmental impact } \\
\text { (emissions, waste management) }\end{array}$ & $\begin{array}{l}\text { investment, health risks) } \\
\text { (management composition, } \\
\text { remuneration, independence } \\
\text { of the management body, } \\
\text { conflicts of interest) }\end{array}$ \\
$\begin{array}{l}\text { Renewable energy sources } \\
\text { (smart solutions, green technology) }\end{array}$ & $\begin{array}{l}\text { Ownership relations } \\
\text { (community involvement) }\end{array}$ & $\begin{array}{l}\text { Corporate culture } \\
\text { (ethical conduct, } \\
\text { transparency) }\end{array}$ \\
& $\begin{array}{l}\text { Promoting social development } \\
\text { (education, poverty eradication) }\end{array}$ & \\
\hline
\end{tabular}

Source: by author, based on MSCI ESG ratings

Corporate social responsibility (CSR) and corporate governance have long been in focus, and banks have undergone significant changes over the past 1.5-2 decades in integrating these considerations into practice and taking them into account in their business decisions. At the same time, it is worth emphasizing that the current elements of the ESG framework are not just about a company thinking responsibly and benefiting society and its operating environment, but that all of these have many benefits in the long run.

By today a significant number of companies have recognized that these aspects are not just empty phrases, and not merely regulatory expectations that must be met, but the cornerstones of sustainable operation. On a daily basis we can hear from many sources about natural disasters (melting of polar ice, destruction of rainforests, etc.), human rights violations (modern slavery, human trafficking, etc.) and corporate fraud and scandals (money laundering, falsification of harmful emissions data, etc.). If any member in the supply chain is affected by such an event, or a company has a strong exposure to such risks, it will affect its operations, so ESG considerations should be reflected in strategic decision-making and 
risk management. This is not easy, however, because a completely new approach needs to be introduced in corporate and risk culture and the benefits can only be realized in the long run.

According to the EU (2019), ESG risks are a potential threat to the stability of the EU financial system. On the one hand, it matters which companies financial institutions finance or what investments they have. On the other hand, ESG events affect the stability of the financial intermediary system. It can also be seen from the investor side that an increasing amount of capital flows into so-called green investments. Many companies deal with ESG-based company valuations, the socalled ESG ratings, which can even serve reputational purposes. ${ }^{3}$ All this reinforces the need and intention for institutions to integrate ESG aspects into their processes. This also means that ESG aspects should be included in disclosures. Although there is currently no dedicated platform for this, sustainability reports provide a picture of a company's non-financial performance, which can also contribute to reputation growth, competitive advantage and, through this, improved financial performance. Friede et al. (2015) analyzed the results of more than 2,000 academic studies published since 1970 examining the relationship between ESG factors and corporate financial performance (CFP). They concluded that more than half of the articles demonstrated a positive relationship between the two factors, with the strongest relationship existing between corporate governance and CFP. Buallay (2019) examined the relationship between each ESG pillar and corporate ROA, ROE and market performance (Tobin's Q). The result of this analysis is a significant positive relationship, but each pillar shows a correlation of different strength and direction. The author also highlighted that

- companies with higher leverage and higher asset value publish more information;

- corporate governance disclosures are more frequent and informative in higher GDP countries;

- in countries with lower GDP, social and environmental disclosures are more detailed.

Through her results, Buallay drew attention to the importance of uniform expectations and regulations.

ESOs themselves provide guidance on the ESG content of listed companies' disclosures. The Sustainable Stock Exchanges Initiative, which deals with the development of an innovative program supported by the United Nations and, among other things, the ESG content of listed companies, provides a good overview. The main tool for

3 For example, the Dow Jones Sustainability Index (DJSI); Morgan Stanley Capital International (MSCI) ESG indices; and Bloomberg ESG disclosure scores. 
this is that stock exchanges themselves set out their expectations and provide guidance to issuers on the content of their reports. Currently 55 stock exchanges have such guidelines. In addition to sustainability reports, companies' ESG awareness can be signalled on other platforms to increase investor awareness and reputation. Although these are not really typical in Hungarian practice, ESG information may appear either in the annual report, in the framework of the fulfilment of the disclosure obligation (risk report), or in separate, targeted reports. A good example of the latter is the parent institutions of two banks operating in Hungary. The Italian UniCredit and Intesa Sanpaolo, for example, have a detailed and comprehensive set of objectives and instruments for "greening" their own operations and portfolios.

To clearly identify preferred and non-preferred sectors for funding - or funded under close monitoring (e.g. mining, oil extraction, the defence industry) - great emphasis is placed on taking into account social aspects, such as the development of micro and small enterprises or the promotion of education and culture. Principles for Responsible Investment (PRI, 2019) concluded that since the year 2000, more and more directives, standards and expectations have appeared that support, encourage and require the consideration of ESG aspects. Some of these also set requirements for the disclosure of ESG information. According to the IIF (2020), the number of mandatory and recommended directives, including disclosure, was close to 200 in June 2020. ${ }^{4}$ The February 2020 BCBS survey on climate risks found that most Member States publish some form of information on climate risks, while only $40 \%$ of responding countries have regulatory guidance on publication. In any case, it is important to develop a common language as a starting point. This is also the aim of the EU Taxonomy Regulation, adopted in $2020^{5}$, which defines a uniform interpretation and uniform classification of sustainability, as well as a system of evaluation criteria.

\section{SELECTED BANKS AND METHODOLOGY}

Based on the above, in the framework of our research we developed a system of criteria and, with the help of content analysis methodology (Mayring, 2000; Zhang and Wildemuth, 2005), assessed the ESG activities of large domestic banks by examining their publicly available sustainability reports and publications (Appendix). The selection of banks was based primarily on market share. The following table shows the list, main numbers and market share of the analyzed banks.

4 The IIF (2020) focused on financial institutions and expectations set by authorities and central banks.

5 Regulation (EU) 2020/852 of the European Parliament and of the Council 
Table 2

Data of surveyed banks

\begin{tabular}{lcccc}
\hline Bank & $\begin{array}{c}\text { Total assets } \\
\text { (million HUF) }\end{array}$ & $\begin{array}{c}\text { Market share } \\
\text { by total assets }\end{array}$ & $\begin{array}{c}\text { Net profit } \\
\text { (million HUF) }\end{array}$ & $\begin{array}{c}\text { Market share } \\
\text { by net profit }\end{array}$ \\
\hline Budapest Bank & 1515148.17 & $3.8 \%$ & 15998.79 & $3.1 \%$ \\
\hline CIB Bank & 2009416.53 & $5.1 \%$ & 13980.80 & $2.7 \%$ \\
\hline Erste Bank & 2862136.18 & $7.2 \%$ & 55536.48 & $10.9 \%$ \\
\hline K\&H Bank & 3554179.29 & $8.9 \%$ & 50414.93 & $9.9 \%$ \\
\hline MKB Bank & 1772455.72 & $4.5 \%$ & 42012.14 & $8.2 \%$ \\
\hline OTP Bank & 10138803.96 & $25.5 \%$ & 193354.34 & $37.9 \%$ \\
\hline Raiffeisen Bank & 2591837.00 & $6.5 \%$ & 20602.39 & $4.0 \%$ \\
\hline Takarékbank & 2167752.26 & $5.5 \%$ & -9848.66 & $-1.9 \%$ \\
\hline UniCredit Bank & 3416391.01 & $8.6 \%$ & 49059.82 & $9.6 \%$ \\
\hline
\end{tabular}

Source: by author based on MNB website

All audited banks publish their reports according to the sustainability topics set out in the GRI Standards. Some publish group-level reports, as the Hungarian bank (e.g. UniCredit or Raiffeisen Bank) does not have a separate report available in Hungarian. At some banks, in addition to the sustainability report, we also find energy and environmental policies. Annual and risk reports for 2019 and information published on websites were also included in the study. The reports come from the banks' websites, in some cases the parent banks.

In developing the criteria, we relied on the elements listed in Table 1, the disclosure guidelines (e.g. stock exchange guidelines for companies), and the reports and information published by banks.

Based on these materials, we compiled a list of 32 questions, dividing the questions into four groups:

- Framework: covers general issues related to the consideration of ESG aspects and their implementation in corporate practice, such as the quantification of ESG risks; their integration into strategy, pricing, supplier requirements and risk management processes; communication of ESG ratings.

- Environmental aspect: covers the emissions of harmful substances, the use of energy, the examination of measures taken for the protection of the environment, and the integration of environmental protection aspects into lending policy. 
- Social aspect: focuses on the bank's social role.

- Corporate governance aspect: examines ethical corporate conduct, issues related to money laundering and compliance with competition rules, and the presence of discrimination in banking operations.

We sought answers to the questions identified in the above four categories in public disclosures. If the answer to a given question was found in the reports, then the analyzed bank received 1 point; if not, it received o points for the year 2019.

After summarizing the responses, we calculated the ESG Disclosure Index (ESGD) using the following formula:

$\mathrm{ESGD}=\frac{\sum_{i=1}^{n} S i}{32}$

where $S_{i}$ is the score for each question, which can be 1 or o, and $n$ is the number of questions in the index, which in this case is 32.

\section{RESULTS}

As a result of examining the public reports of banks, we can determine the value of the ESGD indices for the year 2019. In the case of some banks, where no separate sustainability report was prepared for the Hungarian bank in Hungarian, we also included the parent bank's English-language material containing group-level guidelines in the study.

The results of the calculations are shown in Figure 1.

Figure 1

ESGD indices of Hungarian banks based on 2019 reports

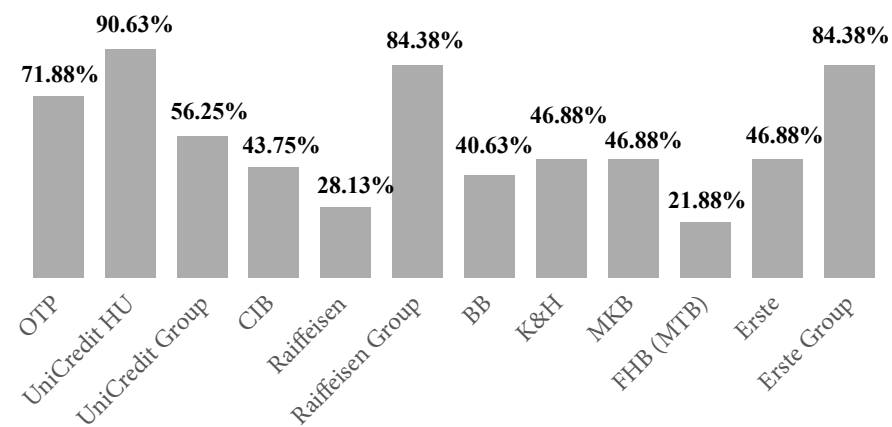

Source: by author 
Based on the chart, we can see that the ESGD indices of large Hungarian banks for 2019 vary between $21.88 \%$ and $71.88 \%$, if we do not take into account the sustainability reports published by the parent banks of foreign-owned banks. If these English-language reports are included in the study, on the one hand the highest ESGD index value measured in the banking sector jumps to $90.63 \%$, and on the other hand we can see that the low ESGD index values of Hungarian subsidiaries increase significantly (e.g. at Raiffeisen, increasing from $28.13 \%$ to $84.38 \%$ ).

It is worth further breaking down the value of the index according to the four aforementioned aspects (ESG framework, environment, social responsibility and corporate governance).

Figure 2 shows the content of the disclosures of Hungarian banks in relation to the ESG framework.

\section{Figure 2}

\section{ESG framework of Hungarian banks based on 2019 disclosures}

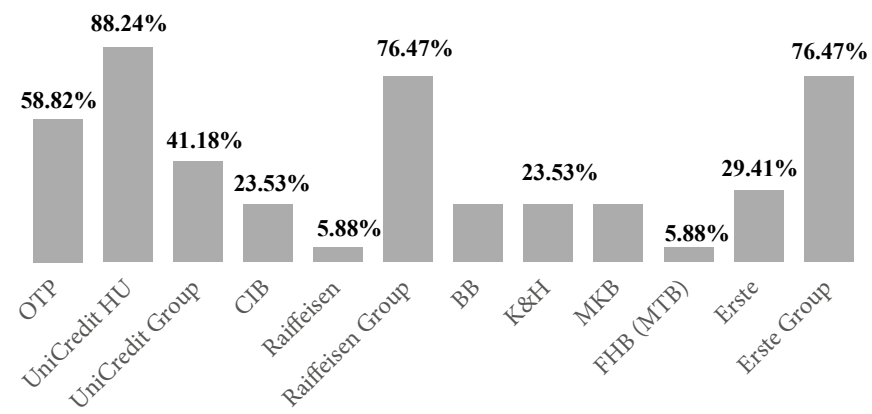

Source: by author

The percentages in Figure 2 show the ratio of answers that were found in the disclosures that included the design of the ESG framework. The results show that Hungarian banks have so far incorporated their environmental, social responsibility and corporate governance efforts into their risk management, strategic processes and lending policies only to a small extent. In the case of foreign-owned banks, the group-level guidelines improve our result, but since these guidelines do not appear in Hungarian reports, it is doubtful to what extent the Hungarian company applies them. In terms of framework, almost all banks omitted to assess ESG risks and systematically integrate them into their risk management processes.

Figure 3 highlights the information on environmental issues in banks' reports. 


\section{Figure 3}

Environmental efforts of Hungarian banks based on 2019 disclosures

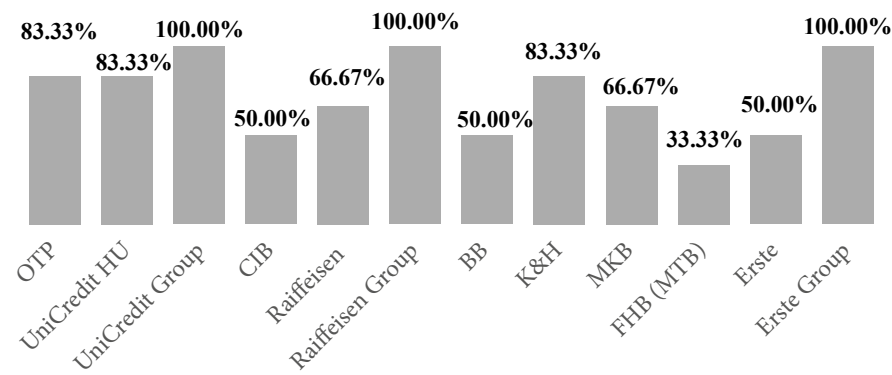

Source: by author

In terms of environmental protection, although the banking sector is not among the industries with a significant impact on the environment, banks can and will take steps to make their operations more environmentally friendly (such as applying selective waste collection, green office solutions). Where we have found shortcomings in the reports, it is in the transformation of lending policy in such a way as to support companies and sectors operating in an environmentally friendly way.

Figure 4 shows the second element of ESG: social responsibility.

\section{Figure 4}

The social role of Hungarian banks based on 2019 disclosures

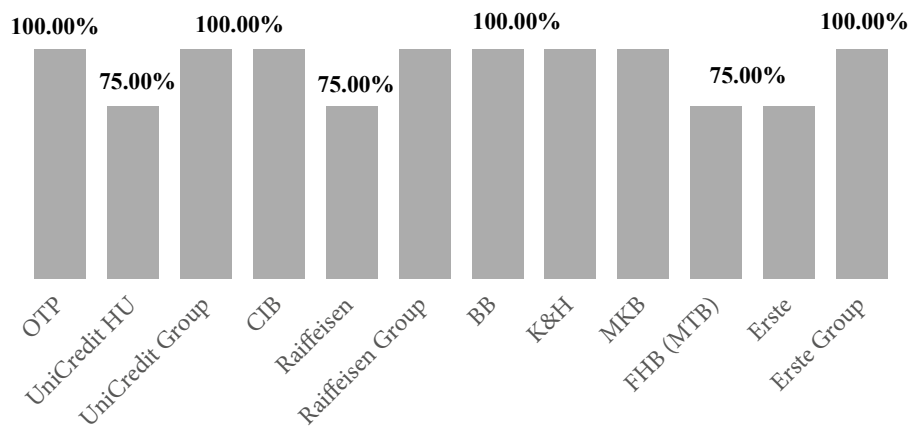


In terms of social involvement, the picture is very positive. Hungarian banks pay special attention to their role in the life of local communities and in the development of financial literacy, helping disadvantaged citizens and providing favourable working conditions.

Figure 5 analyzes bank disclosures in terms of responsible corporate governance.

\section{Figure 5}

\section{Corporate governance practices of Hungarian banks} based on 2019 disclosures

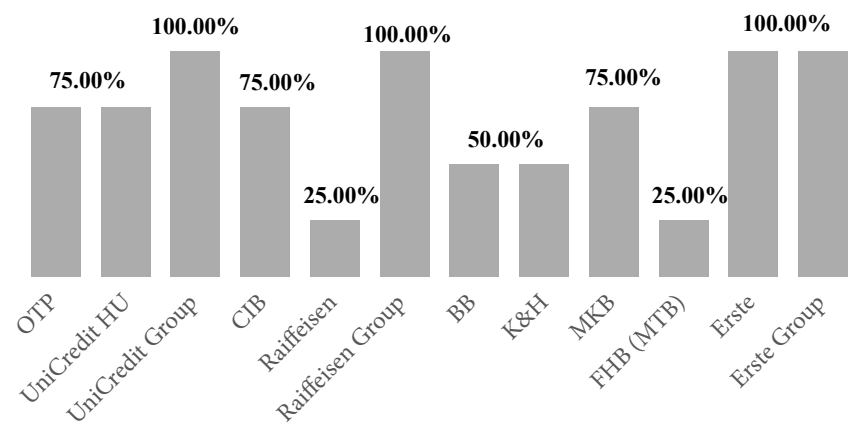

Source: by author

With regard to responsible corporate governance, foreign-owned banks meet the expectations set out in the series of questions only when including the content of their parent banks' reports. However, the overall picture is positive, due to the fact that corporate governance has been a flagship issue for regulators for years.

Based on the content analysis of the reports, we came to the following conclusions:

1) We found that the development of a unified ESG risk management framework did not take place among domestic banks. ESG risks have not been integrated into risk management systems. Banks do not define ESG risk as a standalone risk. The framework does not have a dedicated organization.

2) ESG risk management is unstructured, inconsistent or rudimentary (appearing in practice in Hungary, where institutions have taken only the initial steps).

3) In the absence of a uniform, standardized disclosure requirement, heterogeneous reports and information content are common. We see a need for both regulation and banking practice to move towards uniform disclosure standards. 
4) With respect to the three issues (environment, social responsibility, corporate governance), banks lag far behind in environmental efforts. We see the main shortcoming in integrating environmental and sustainability considerations into lending policy.

5) In the practice of foreign banks and companies, there are many positive examples of commitment to managing ESG risks. Knowledge of these examples can help create a good framework and at the same time can be a significant driving force in developing the ESG awareness of domestic banks. In the case of foreign-owned banks, the parent's banking practice can serve as an excellent guide in developing "best practice."

Some individual examples could be emphasized. Implementation of an ESG framework into business and risk management processes requires the commitment of a bank's management. OTP Bank could be highlighted in relation to this aspect, because - according to its Sustainability Report - one sustainability goal is included among the aspects of remuneration from 2020.

The OTP group assesses and evaluates the impacts of climate change within its operational risk management framework - especially under scenario analysis. ${ }^{6}$

\section{CONCLUSION}

In the course of our research, we reviewed the annual, risk and sustainability reports of large Hungarian banks and, based on 32 questions, examined the level of development of banks in terms of managing ESG risks and integrating ESG aspects into corporate operations and corporate culture.

Overall, it can be seen that there is room for improvement. In parallel with the increase and tightening of regulatory and investor expectations, significant changes can be expected in the next 2-3 years.

While we have increasingly seen green investments in the banking product range, these aspects are less prevalent in lending. However, it is through lending - as one of its core activities - that the banking sector can do the most to promote sustainability.

The essence of comprehensive enterprise risk management is to take into account all the risk factors that affect corporate value creation. ESG risks are no exception. As the risks do not exist on their own, but appear in close interaction in banking operations, it is essential that a unified ESG risk management framework

6 OTP assesses risks arising from climate change within the Natural disaster, Outage of public utilities, and Collateral management scenarios. 
is developed as an independent area with the commitment and support of top management.

Implementing the ESG framework generates costs in the short term, even significant ones, but its benefits can be exploited in the longer term, for example through improved financial performance or an improvement in reputation.

\section{APPENDIX}

\section{The ESG activities of large domestic banks by examining their publicly available sustainability reports and publications}

\begin{tabular}{|c|c|c|}
\hline Number & Question & Category \\
\hline 1 & $\begin{array}{l}\text { Do the mentioned sources (reports and website) show } \\
\text { the ESG risk and the interpretation of each aspect } \\
\text { (e.g. definition, content, interpretation, significance)? }\end{array}$ & Framework \\
\hline 2 & $\begin{array}{l}\text { Do these sources (reports and website) } \\
\text { show the bank's emissions? }\end{array}$ & Environment \\
\hline 3 & $\begin{array}{l}\text { Do these sources (reports and website) show } \\
\text { the bank's energy consumption (e.g. at least one } \\
\text { of water consumption, electricity or paper, etc.)? }\end{array}$ & Environment \\
\hline 4 & $\begin{array}{l}\text { Do these sources (reports and website) reflect measures } \\
\text { taken to protect the environment and sustainability? }\end{array}$ & Environment \\
\hline 5 & $\begin{array}{l}\text { Do these sources (reports and website) reflect } \\
\text { the bank's longer-term vision for the environment } \\
\text { and sustainability? }\end{array}$ & Environment \\
\hline 6 & $\begin{array}{l}\text { Do these sources (reports and website) include } \\
\text { a set of criteria for workers (e.g. work atmosphere, } \\
\text { protection of workers, physical safety, health, } \\
\text { promotion of sport, non-discrimination, joint } \\
\text { programs, strengthening loyalty, etc.)? }\end{array}$ & Social \\
\hline 7 & $\begin{array}{l}\text { Do these sources (reports and website) show } \\
\text { an ESG-focused expectation for suppliers? }\end{array}$ & Framework \\
\hline 8 & $\begin{array}{l}\text { Does the bank emphasize that green products } \\
\text { (e.g. investment funds) are available in its portfolio? }\end{array}$ & Environment \\
\hline 9 & $\begin{array}{l}\text { Do these sources (reports and website) include action } \\
\text { plans to increase customer confidence (e.g. data } \\
\text { security, protection of personal data)? }\end{array}$ & Social \\
\hline 10 & $\begin{array}{l}\text { Do these sources (reports and website) show the grants, } \\
\text { donations and developments financed by the bank } \\
\text { (e.g. SMEs, non-profit enterprises, foundations)? }\end{array}$ & Social \\
\hline 11 & Is there a mix of women and men on the board? & Governance \\
\hline 12 & Are ESG aspects included in remuneration policy? & Framework \\
\hline 13 & Are clear, representative reports available on the topic? & Framework \\
\hline
\end{tabular}




\begin{tabular}{|c|c|c|}
\hline 14 & $\begin{array}{l}\text { Do these sources (reports and website) provide } \\
\text { information on corporate ethics? }\end{array}$ & Governance \\
\hline 15 & $\begin{array}{l}\text { Do these sources (reports and website) include } \\
\text { measures to prevent money laundering and financing } \\
\text { of terrorism? }\end{array}$ & Governance \\
\hline 16 & $\begin{array}{l}\text { Does the bank emphasize that compliance with } \\
\text { competition rules is of paramount importance } \\
\text { in its operations? }\end{array}$ & Governance \\
\hline 17 & $\begin{array}{l}\text { Do these sources (reports and website) reflect } \\
\text { the bank's actions in relation to conscious finance } \\
\text { and the development of financial literacy? }\end{array}$ & Social \\
\hline 18 & $\begin{array}{l}\text { Are ESG aspects and risks addressed by a dedicated } \\
\text { organization? }\end{array}$ & Framework \\
\hline 19 & $\begin{array}{l}\text { Has senior management's commitment been revealed } \\
\text { in relation to all three aspects? }\end{array}$ & Framework \\
\hline 20 & $\begin{array}{l}\text { Have ESG aspects been integrated into risk } \\
\text { management? }\end{array}$ & Framework \\
\hline 21 & Are ESG aspects and risks discussed by committee? & Framework \\
\hline 22 & Are ESG aspects mentioned in a strategic context? & Framework \\
\hline 23 & $\begin{array}{l}\text { Has risk appetite (even tolerance) been defined } \\
\text { for ESG? }\end{array}$ & Framework \\
\hline 24 & $\begin{array}{l}\text { Does the bank address ESG aspects through BCP, } \\
\text { scenarios, and stress tests? }\end{array}$ & Framework \\
\hline 25 & $\begin{array}{l}\text { Does the bank take ESG considerations into account } \\
\text { when selecting customers and pricing? }\end{array}$ & Framework \\
\hline 26 & $\begin{array}{l}\text { Do the mentioned sources (reports and website) } \\
\text { show the ESG rating? }\end{array}$ & Framework \\
\hline 27 & $\begin{array}{l}\text { Do these sources (reports and website) show } \\
\text { the sectors preferred and non-preferred by the bank in } \\
\text { terms of lending (sectors not financed, or financed only } \\
\text { within strong limits, e.g. mining, defence industry, etc.) }\end{array}$ & Environment \\
\hline 28 & $\begin{array}{l}\text { Do consumer protection and competition authority } \\
\text { fines appear in these sources (reports and website)? }\end{array}$ & Framework \\
\hline 29 & $\begin{array}{l}\text { Does the bank emphasize the importance of climate } \\
\text { protection and the risks of climate change? }\end{array}$ & Environment \\
\hline 30 & $\begin{array}{l}\text { Are banking risks mentioned as ESG risks } \\
\text { (as a separate category)? }\end{array}$ & Framework \\
\hline 31 & $\begin{array}{l}\text { Does the bank also mention ESG aspects in its annual } \\
\text { report? }\end{array}$ & Framework \\
\hline 32 & Does the bank quantify ESG risks or exposures? & Framework \\
\hline
\end{tabular}




\section{REFERENCES}

BCBS (2020): Bank for International Settlement. Climate related financial risks: a survey on current initiatives. April.

BuAlLAY, A. (2019): Is sustainability reporting (ESG) associated with performance? Evidence from the European banking sector. Management of Environmental Quality 30(1), 98-115, https://doi. org/10.1108/MEQ-12-2017-0149.

European Union (2019): Risks and vulnerabilities in the EU Financial System. Joint Committee report, Autumn.

Friede, G. - Busch, T. - BASSEN, A. (2015): ESG and financial performance: aggregated evidence from more than 2000 empirical studies. Journal of Sustainable Finance \& Investment 5(4), 210233, https://doi.org/10.108o/20430795.2015.1118917.

IIF (2020): Institute of International Finance. Building a Global ESG Disclosure Framework: a Path Forward.

Mayring, P. (2000): Qualitative Content Analysis. Forum: Qualitative Social Reseach 1(2), June.

PRI (2019): Taking stock: Sustainable Finance Policy Engagement and Policy Influence. Principles for Responsible Investments, UNEP Finance Initiative, UN Global Compact, https://www.unpri. org/Uploads/c/j/u/pripolicywhitepapertakingstockfinal_335442.pdf.

Zhang, Y. - Wildemuth, B. M. (2005). Qualitative analysis of content. Analysis 1(2), 1-12. (https:// philpapers.org/rec/ZHAQAO, downloaded at November 2017).

Banks' web pages 